\title{
Poverty in Transition: An Ethnographic Critique of Household Surveys in Post-Soviet Central Asia
}

\author{
By
}

Deniz Kandiyoti

1999

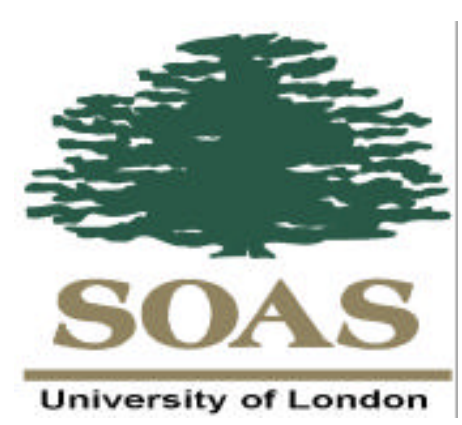

Centre for Development Policy \& Research (CDPR)

School of Oriental and African Studies, University of London

Thornhaugh Street, Russell Square, London WC1H 0XG, United Kingdom

Telephone: +44 (0)20 7898 4496,

Fax: + 44 (0)20 78984519 ,

E-mail: CDPR@soas.ac.uk

URL: http://www.soas.ac.uk/centres/cdpr 


\begin{abstract}
Post-Soviet transitions have prompted a search for new policy tools and methods of data collection. The shift from universal welfare provision under the Soviet system to targeted assistance and poverty monitoring has stimulated a new interest in the measurement of living standards and poverty lines. This has promoted the use of quantitative techniques and sample surveys (household surveys, in particular) as privileged tools for the collection of policy-relevant information. This paper contends that survey techniques have particular limitations as research tools in an environment where local level case studies are scarce and where a host of new socio-economic processes are creating fundamental shifts in the landscape of social provision, redistribution and employment. These limitations are illustrated by drawing upon a household survey conducted by the author in four villages from two regions in Uzbekistan, Andijan and Kashkadarya, between October 1997 and August 1998. The ambiguities surrounding five basic concepts, those of household, employment, access to land, income and expenditure are discussed in detail, as are the changes in their contents and meanings in the context of transition. The gender differentiated outcomes of current changes and their possible implications are highlighted throughout the text. The conclusion suggests that Uzbekistan finds itself at an uneasy juncture where the policies deployed to 'cushion' the social costs of transition may reach the limits of their sustainability. A more contextually sensitive approach to the mechanisms that generate new forms of vulnerability and the use of qualitative and longitudinal methodologies are essential to an adequate monitoring of further changes.
\end{abstract}

\title{
Introduction
}

Transition to the market in the former Soviet Union has occasioned an extensive overhaul of the statistical and planning apparatuses inherited from the Soviet period in all the newly independent states, including the republics of Central Asia. The creation of a new informational infrastructure, prompted by the demands of major international donor and lending agencies, appears to be an intrinsic, if little noticed, adjunct of market reforms. Part of the rationale behind these changes is to bring certain indices and measurements (such as definitions of employment, the measurement of prices, living standards and poverty) into line with internationally agreed standards set by bodies such as the ILO, WHO, OECD and the IMF. The data collection tools inherited from the era of central planning ( such as the Soviet Union Family Budget Survey ) are being revised and modified while, simultaneously, a range of externally funded sample surveys are being carried out (see Falkingham and Micklewright, 1997, for details). The shift from universal welfare provision under the Soviet system to 'targeted' assistance and poverty monitoring also requires the development of new policy tools. These changes are still in their early stages if we consider, for instance, that the Poverty Assessments (PAs) carried out in many countries by the World Bank (see Whitehead and Lockwood, in this volume) and the use of Participatory Poverty Assessments (PPAs) have only just started. The same applies to Living Standard Measurement Surveys (LSMS) which are also new to the 
region. However, the design and implementation of development projects funded by various donor agencies has created a growing demand for social and economic data and the volume of social research conducted in the private and NGO sectors has increased substantially. This has resulted in a proliferation of sample surveys, mainly based on closed-ended questionnaires and relying on quantitative techniques of data analysis. In particular, household surveys have emerged as a prime tool for generating policy relevant information.

The main contention of this paper is that transition economies present us with specific methodological and conceptual challenges that need to be adequately reflected in research designs. In the absence of an in-depth understanding of the local meanings attached to the categories that are most routinely employed in questionnaires and interview schedules, survey findings can be of limited utility, and may even be quite misleading. This is not to suggest that the sources of error and bias discussed in the remainder of this text are in any way unique to the post-Soviet context. I am arguing, nonetheless, that the limitations of survey methodologies may become even more acute in settings where there is a serious scarcity of local level case studies that may assist the analysis of socio-economic processes that are generative of new forms of vulnerability. This is particularly pertinent to achieving an understanding of genderdifferentiated outcomes of transition since these are embedded in local cultural practices and expectations. The relatively modest compendium of ethnographic and sociological research produced during the Soviet period is not only outdated but the drying-up of research funds since the break-up of the Union has meant that social science research- which was relatively weak in the Central Asian region in the first place- has come to a standstill. This vacuum is now been filled by surveys, mainly commissioned by external donors, in a context where local sociological and anthropological research has ground to a virtual halt.

In what follows, I will argue that surveys may not be the most appropriate research tools in an environment where a host of new and, thus far, uncharted socio-economic processes are producing fundamental alterations in the landscape of social provision, redistribution and employment. These changes are at the root of new forms of poverty which need to be analyzed and interpreted in their regionally and culturallyspecific contexts. In particular, I will attempt to show how the combination of Soviet categories of 'official' registration, local cultural understandings and recent changes introduced by agrarian reforms may act to foil the best intentioned attempts at receiving meaningful answers to seemingly straightforward questions.

My illustrations will be drawn from a household survey conducted in four villages from two regions of Uzbekistan, Andijan and Kashkadarya, between October 1997 and August 1998. ${ }^{1}$ The survey was preceded by in-depth household case studies and detailed observations in order to avoid errors and biases stemming from the lack of adequate qualitative information. The dangers of such oversight were brought home to me by the results of the EUI/Essex Survey carried out in 1995 in three regions of Uzbekistan. This survey attempted, among other things, to estimate the incidence of private transfers among households, whether these take the form of gifts, exchanges or loans in cash or in kind (Couduel, Mc Auley and Micklewright, 1997). This information was obtained by asking household heads or other persons answering the questionnaire whether they had received help from relatives or friends in the thirty days prior to the interview. Although the survey established that a substantial number 
of households had been involved in either making or receiving cash or in kind transfers, it completely missed out on the most pervasive mechanism for private transfers, namely gaps. Gaps are social get-togethers functioning as rotating savings associations where all the members of a network pay in a fixed sum of money each month which they receive as a lump sum when it is their turn to hold a gathering at their own home. ${ }^{2}$ Since these networks are primarily presented- and experienced- as venues for recreation and sociability there is no reason why they should have been reported in answer to the question posed. Yet gaps account for the largest volume of cash in circulation based on private transfers. These sums help to alleviate the shortage of ready cash and assist in making more important purchases or defraying non-routine expenses. However, the cultural embeddedness of gaps meant that their economic functions could escape detection altogether (Kandiyoti, 1998).

Despite a high level of awareness concerning the possibility of such errors, the household survey referred to throughout this text, nonetheless, highlighted the intrinsic ambiguities of some of the categories employed and the limitations of the survey as a tool in a context where the meanings attached to many concepts are in a state of flux. ${ }^{3}$ More specifically, I shall describe these difficulties in relation to five central concepts, namely, those of household, employment, access to land, income and expenditure. I shall attempt to illustrate how the contents of these categories are not only context-specific but are also shifting in response to changes in the rural environment of Uzbekistan. Since these concepts also constitute the basic building blocks used in conventional measurements of poverty, this critique is of more general relevance to an assessment of changing living standards in transition economies.

\section{Households: elusive boundaries}

The household (or domestic unit) generally refers to a group of co-resident persons who share most aspects of consumption and draw upon a common pool of resources for their livelihood. However, the sheer diversity of patterns of rural householding documented in ethnographic accounts makes this definition too simplistic and renders the concept itself rather elusive. On the other hand, 'official' definitions of what constitutes a household, deployed for the purposes of enumeration and the delivery of social benefits and entitlements, have an undeniable concreteness. The effects of these definitions may not be overlooked, although they may take different forms in different contexts.

There are a significant differences between studies of households carried out in the industrialized West and those based in the less industrialized economies of the South. In the case of the former, the state and the welfare system are acknowledged as important agents informing both livelihood strategies and decisions about employment and the allocation of household tasks and budgetary resources (see for instance, Morris, 1984,1987; Pahl,1984,1988). In the latter, there is generally little reference to the role of supra-household or non-kin based agencies, reflecting the weakness or absence of social safety nets, especially in rural areas. Societies that have experienced collectivization occupy a rather distinctive place in this respect since their rural populations have access to a range of benefits and entitlements through membership in collective enterprises and state welfare legislation. However, here as elsewhere, the question of the degree of 'fit' between the actual practices of 
entities registered as households and the official assumptions made about them constitutes a vexed and complicated issue. ${ }^{4}$ Rural households in Uzbekistan present specific problems for researchers using standard sampling techniques based on selsoviet (village administration) records, the most commonly used sampling frame for surveys. This is due to the fact that the relationship between official registration as separate units of co-residence and actual separateness as budgeting and production units can be quite tenuous and variable.

Physically, rural domestic units cluster around a courtyard (auli) where the garden plot, poultry and animals may be kept and where separate living quarters may be built for married sons. A distinction is made in the Uzbek language between household (hodjalik) and family (oila), and multiple family households are quite commonplace. Post-marital residence is virilocal and although it is typically the youngest son who inherits the parental home and cohabits with elderly or widowed parents, other married sons are, if possible, accommodated around the same auli. Some sons may leave the courtyard altogether and set up residentially and financially separate households. This becomes inevitable when there is no spare plot to house them or when circumstances take them elsewhere. Parental expectations of co-habitation with at least one married son are high although, in practice, many households diverge from this pattern. Married couples working for collective enterprises that provide them with purpose built apartment accommodation (zhil dom) tend to lve in smaller household units. Elderly couples who have no sons or co-resident unmarried children may be found living either on their own or with grandchildren.

Within this framework, village records provide an imperfect guide to the actual number of households since there is a tendency for families, whether they are coresident in the same auli or not, to register as separate units. This entitles them to separate private plots and to child benefit and income support when their income falls below a certain level. ${ }^{5}$ Moreover, families sharing the same courtyard may have different budgeting arrangements. In local parlance, they may either 'share the same kazan bir) or keep separate pots (kazan alahada) and constitute separate budgeting units. The decision to share daily consumption or otherwise involves a wide range of considerations, both monetary and relational, and may undergo modifications depending on changing circumstances.

Mindful of these distinctions, the interview schedule used in the survey referred to above did not simply take the households registered in the selsoviet records at face value, but also ascertained whether they had separate cooking pots or not. Such was the case of Omina and Abdulkarim, a newly married couple, who had set up a residentially separate household and reported keeping a separate budget and "their own" cooking pot. However, they had not been allocated a private plot, apart from the land on which their house was built, and appeared to have no visible means of support since the one was unemployed and the other a kolkhoz worker who had not received wages for months. It is only later, in connection to questions on crops harvested and sold, that it became apparent that this couple was still working on the plots of Abdulkarim's paternal household and receiving a portion of their harvest and income. This was a clear-cut case where the separation of residence and daily consumption gave few clues on the actual allocation of agricultural and other tasks among married sons. Corrective action by he researcher was clearly needed here to reconstitute the full domestic unit that made this young family viable. Indeed, families that do not 
cook and live together may nonetheless continue to cultivate common plots, share the produce and remain enmeshed in daily ties of sharing and exchange of products, labour and services structured along gender and seniority lines. This type of corrective action may be particularly difficult to accommodate in large scale surveys based on fixed sampling fractions and using teams of interviewers, assuming that local variations in budget control had been identified in the first place.

Conversely, common residence and a shared cooking pot may act to conceal the tacit separation of incomes and expenditures of co-resident families. Zuhra and Sodik are elderly pensioners cohabiting with a married son, his bride (kelin) and their unmarried children. They report cooking together. However, when asked about who keeps the household money and who asks for money from whom when necessary, Zuhra says; 'We keep and spend our own pension. They keep their own money'. Although they may share the produce of their land plots, they go their separate ways when it comes to cash expenditure. This tendency may have been exacerbated by the fact that pensions have become the sole source of cash income in many households where kolkhoz workers are paid intermittently and only in kind. Clearly, depending on circumstances, such sharing arrangements may be revised and modified. In one case, a widowed pensioner, Omina, decided to separate her cooking pot from her elder son, who already has four children, and to share her pension income only with her youngest married son who has no regular income and a disability. She justifies her initiative as follows : 'Why should I share my pension with all of them ? The older children grow, the more they eat. To each his own, it's better that way'.

To complicate matters further, relational considerations may exercise a considerable influence on the reporting of even the most seemingly straightforward items. The household survey in Andijan and Kashkadarya also included interviews with all cohabiting, adult women. This often meant that mother-in-law/daughter-in-law pairs had to answer the same questions (albeit separately). Concerning the ownership of household durables ( such as televisions, sewing machines or furniture ), the answers of co-habiting pairs tended to be identical, which was what one would normally expect. There was, however, a notable exception of a daughter-in-law who reported owning only a cupboard, the one she had brought with her trousseau, omitting to mention other household items that were plainly available. When I queried this apparent anomaly, I was informed that this kelin was having a particularly bad relationship with her mother-in-law. This was evidently her way of signalling her disaffection with and alienation from her husband's family. In a rare twist of events, there was also one case of a bride reporting a car among household possessions, an item that was left out of her mother-in-law's account. This was a case where the older woman only had access to her pension money, whereas the bride claimed to be in control of general household finances.

These findings suggest that different levels of welfare and access to resources may apply to different categories of household members, depending on gender, seniority and the state of interpersonal relations between genders and generations. Although it has almost become a truism, especially in feminist literature, to point out that intrahousehold relations mediate individual access to resources ( Bruce and Dwyer, 1988; Moore, 1992; Agarwal, 1990; Evans, 1989; Whitehead, 1981), these age-gender effects are not necessarily captured by household surveys unless they are specifically built into questionnaire designs. In the case of the household survey in Andijan and 
Kashkadarya, interviews with all co-resident adult women were extremely revealing with respect to intra-household discrepancies in access to income and leisure.

There were are at least three areas that pointed to significant disparities within households; budget control, access to money and to leisure. Most women reported that the money in their household was kept either by their husband, or their father-in-law or mother-in-law. This meant that many women in waged employment handed over their earnings and had to approach the holder of the purse strings if they needed cash. Furthermore, as will be explained in greater detail in the sections dealing with employment and income, there are now more women than men who are either unemployed or are receiving their wages only in kind. These varying levels of discretion over money became quite apparent in the age composition of participants in all-women gaps, the rotating savings networks referred to above. Younger married women (kelins) do not generally participate in such occasions and if they do it is usually by consent of husband and mother-in-law. If a household is better off, the kelin may be allowed to use the gap money on herself. Normally, she hands the money over and is expected to do so. There may be conflicts in cases where the kelin who earns her own money and contributes to the gap through her own means feels resentful about having to hand over the proceeds to her husband or mother-in-law. In most instances, however, these hierarchies of domestic privilege are perceived as quite natural.

The distribution of domestic chores is also skewed in the direction of younger women who have a much longer working day. They are responsible for the more routine and onerous tasks of cleaning, fetching water, washing clothes, tending animals and the kitchen garden. Older women may oversee these activities and continue to cook, bake and keep an eye on children although they tend to delegate the more back-breaking tasks, such as kneading dough for bread, to their daughters-in-law or adolescent daughters. Adult men are usually exempt from domestic chores, although boys may be asked to fetch and carry, run errands and take care of animals. Age and gender therefore structure intra-household divisions of labour and access to leisure in powerful ways.

Patterns of intergenerational assistance and solidarity are shaped to a considerable extent by the patrilineal bias inherent in the local kinship system. Three of the most vulnerable households, bordering on destitution, consisted of elderly pensioners who only had married daughters and no sons. In one case, gandchildren had moved in to give the elderly couple a hand. In the other cases, although the daughters came in to help with household chores they did so on sufferance from their husbands. The elderly couples received no help at all with their household plots and had to lease them out. It is too early to speculate whether increasing dependence on offspring will give a further boost to already existing son-preference in Uzbekistan. At this point in time, there is some evidence to suggest that pensions, though much reduced in value, are still appreciated as a source of cash. Humphrey, for instance, cites a respondent in Siberia as saying 'It is better to have two live grandparents than to have two cows' (1998: 465). However, I did not encounter any cases where a widowed woman was taken into a married daughter's household whereas widowed mothers of sons were routinely to be found in control of household finances, sometimes at a surprisingly advanced age. Some responses to a question concerning the number of co-resident families in a household suggested that both emotional and cultural considerations 
played a role in delineating boundaries. In some cases, widowed parents, with or without unmarried children, were considered to constitute a separate family, in other cases they were not. Divorced daughters who came back to live with their parents, with or without children, were considered as a separate family, pointing to the anomalous, and hopefully transitory, nature of their current status. ${ }^{6}$ Neither the boundaries of constituent families within households, nor those between households are fixed entities. Rather, they may themselves become the object of negotiation and redefinition, depending on a range of material and emotional circumstances.

Domestic units are, therefore, best conceptualized as the site of multiple and interlocking sets of processes. These may activate different sub-sets of individuals who constitute appropriate units of analysis, depending on the nature of the research question posed. For instance, an understanding of family planning decisions may require a different unit of analysis than, say, the allocation of intra-household resources. Since the exploration of these boundaries is part and parcel of the research process, there is a sense in which units of analysis may sometimes emerge $a$ posteriori. An adequate understanding of the different ways in which domestic units organize livelihoods and mutual assistance is particularly central to analyses of vulnerability, especially in a context where existing social safety nets are being eroded, and must be given the utmost priority. Gender analyses of poverty are more crucially dependent upon an accurate identification of the hierarchical allocational practices and power differentials enacted in domestic units.

The household survey in Andijan and Kashkadarya revealed that the links between co-residence, budget control and household divisions of labour (in both domestic and production tasks) are varied and complex as well as fluid. It also highlighted significant intra-household disparities in budget control, access to income and to leisure.Even the use of so-called 'filter questions' (in this particular case, trying to sort out households with a common vs. separate cooking pot at the outset) proved unequal to the task of identifying the boundaries of domestic units. Yet the general tendency in survey research is to assume that households correspond to officially registered units of residence and that these, in turn, constitute discrete budgeting units. A more flexible and exploratory approach clearly needs to be adopted, one that is more open to trial and error. The qualitative methodologies habitually employed at the pilot stage of surveys, whether these take the form of focus group discussions, participatory or observational techniques, may not be sufficient in themselves to secure adequate questionnaire design. However, an unexpected bonus of the survey method may reside in the heuristic value of the inconsistencies, gaps and apparent inaccuracies of the responses provided- what are normally dismissed as 'errors' rather than given detailed consideration. This is what the rest of this paper will attempt to demonstrate, starting with the category of 'employment'.

\section{Employment vs. livelihoods ?}

Although it is a commonplace that the concept of employment is itself an artifact of regulation (as most discussions on the informal economy keep reminding us), this is nowhere more apparent that in the republics of the former Soviet Union. In the case of our survey, a strikingly high proportion of respondents declared themselves 'unemployed', even as they gave detailed descriptions of their farming, animal 
husbandry or trading activities. This was not an attempt at dissimulation; they were, indeed, 'officially' unemployed.

In the Soviet Union ( and currently in Uzbekistan) all employees are provided with a workbook (trudovaya knizhka in Russian, or mihnat daftarchasi in Uzbek) which is registered with their employer for the entire duration of their time with that enterprise. If a workbook is "with the person himself/herself" rather than with an employer this constitutes an interruption of service and reflects detrimentally on pension rights (with the exception of one and a half years allowed for maternity leave, or dekret). It is therefore important to keep one's workbook registered with an enterprise whether one is drawing a salary or not.

Alisher Ilkhamov ( 1998 ) notes the fact that farm restructuring in Uzbekistan consisted mainly of converting state farms, which were centrally funded, into collective farms which hold their own budgets. As a result, there was a thirty per cent increase in collective farms since 1991 and privatization took the rather cosmetic form of restructuring them as joint-stock companies now called shirkat. Since these enterprises are in permanent deficit, the pressure of having to pay salaries has resulted in either shedding some of their personnel or keeping them on the books without paying them wages. These new pressures created different categories of employees; those registered, and still receiving a salary (generally in managerial positions), those registered, without receiving a salary ( some skilled workers who now work on their own account), those registered, but receiving irregular payment and only in kind (unskilled agricultural workers), and those who are struck off the books altogether and 'keep their own workbook'. These latter identify themselves as unemployed, regardless of what else they do and how much they earn. There are, in addition, different categories of non-employed. Housewives who are currently out of a job will report themselves as unemployed, whereas those who have never had a workbook will define themselves as housewives. Invalids receiving disabiliy benefit, students with stipends, women on maternity leave, and pensioners constitute recognized categories of non-employed, distinctions that are seldom found in rural societies where such provision is non-existent.

It is also important to note that post-Soviet reforms have not been gender-neutral in their effects. Most commentators have pointed to the disproportionate rise in female unemployment in transitional economies (Moghadam,1993; Molyneux, 1994; Buckley, 1997). In the labour surplus areas of Central Asia, the majority of those working outside social production were already identified as women before the breakup of the Union (Lubin, 1981). This existing tendency for female unemployment and underemployment has become further exacerbated, in both rural and urban areas, by the continuing loss of public sector jobs although women constitute a major proportion of collective farm workers, especially in the seasonal operations of cottonpicking. One of the paradoxes of transition has been a simultaneous intensification of women's labour input into a range of subsistence and informal activities, more fully described in the next section, accompanied by a decline in their wage-earning opportunities and incomes.

Among the 'officially' employed, current patterns are also getting increasingly complex, especially in urban areas. There are people who are registered with an enterprise for pension purposes but do not do the job they are registered for, nor do they draw a salary. There are also those who are registered in an enterprise, and do 
another job entirely. Not surprisingly, with the collapse of public sector employment and precipitous drops in wages what used to be 'subsidiary' activities or 'unofficial' incomes now often become the mainstay of household budgets. However, for the purposes of surveys (an official activity par excellence) many will still report the place where their workbook is registered, and the 'official' salary that goes with it, regardless of what they actually do to make a living and how much they might actually earn.

This was quite apparent among registered shirkat workers in the survey (constituting the majority of rural workers) who reported a monthly wage that had by now become quite fictitious. This makes the calculation of household incomes quite problematic, as will be seen in the sections to follow. There is a sense in which this insistence on official wages has to do, at least partly, with a desire by respondents to depict their current situation as somehow 'anomalous', a situation that could not last indefinitely and might, again, be put right. Especially now that no stigma attaches to informal activities, which are no longer considered illegal, this tenacity cannot be attributed to attempts at concealment. This could hardly be the case in the context of a survey where all other sources of income were gone into in considerable detail. I had to acknowledge the extent to which local understandings of what constitutes a 'proper' job and the benefits that go with it had been deeply conditioned by Soviet institutions. The sense of grievance experienced by those subjected to late payment of benefits, for instance, also conveyed a sense of outrage about a loss of normalcy. It is, of course, conceivable that a major overhaul of the welfare system and phasing out the workbooks in favour of different arrangements may, in time, change people's apprehensions and expectations. It is also clear that this is an area where a great deal of resistance is likely to manifest itself. ${ }^{7}$

What is directly pertinent to the argument at hand, is that extreme vigilance is necessary when formulating questions on current employment status. The issue of whether salaries are actually received or not, at what intervals, the calculations of money equivalents of in kind payments and the extent to which currently non-salaried jobs offer scope for non-official wages to be earned ${ }^{8}$ must all be taken into account. This is difficult to achieve in view of an understandable reticence to report unofficial earnings. Informal activities, such as trading in markets, are reported with greater ease. These activities are, in fact, subject to regulation since it is necessary to register and pay the bazarkom (the officer in charge of allocating spaces and collecting charges) for one's stall or spot. On the other hand, it is common knowledge that although a bazarkom's official wages may be quite low this is a sought after and profitable position offering plenty of opportunities for unofficial emoluments which provide a handsome supplement. This is a point I shall return to in greater detail when discussing the question of household incomes.

But first we must consider the crucial question of access to the main source of rural livelihood, namely land.

\section{Access to land: moving the goal posts?}

Among the republics of Central Asia, Uzbekistan is noted for pursuing a gradual strategy of partial changes in the area of agrarian reform (Spoor, 1995; Ilkhamov, op.cit.). Unlike neighbouring Kazakhstan and Kyrgyzstan, there has not been a 
disbanding of kolkhozes but rather the creation of what Ilkhamov has described as a three-tiered rural economy. This structure consists of collective farms, still occupying the major part of irrigated, arable land, a thin layer of private peasant farms, and a mass of collective farm employees who cultivate household smallholdings. Ilkhamov has cogently argued that the local elite has a stake in the maintenance of this type of agrarian economy since it ensures a minimum subsistence level for the peasantry whilst preserving the monopoly of the government and administrative elites over land and water resources and over cotton, the leading and most lucrative export commodity

However, despite the absence of de jure privatization, land is de facto increasingly becoming a commodity through the development of leasehold markets. Local administrations and collective farms face the contradictory pressures of having to simultaneously fulfil state procurement quotas for crops (cotton and wheat), continue to allocate private plots to households for their own use and entering leasehold arrangements with farmers under the new rules of the Land Law. This is creating an unprecedented indeterminacy in the mechanisms of land allocation.

Villagers have access to different types of plots. The first type is the land plot on which their house is built and may accommodate a small kitchen garden. This is held in perpetuity and is inheritable. The second type is the tamorka or private subsidiary plot to which all citizens have been entitled since Soviet times. After independence in 1991 the legal size of personal plots was increased substantially, from 0.1 ha. to 0.25 ha. of irrigated land and 0.5 ha. of non-irrigated land. These are usually allocated from the land reserves of collective farms and, in densely populated areas, may be located some distance away from house plots.

On the collective farm itself, two types of land tenure arrangements may coexist; leasehold peasant farms and sharecropping arrangements with farm management on annually negotiated terms. In principle, leasehold peasant farms are free to market their own produce but, in practice, they also opt for a sharecropping arrangement with the collective farm on which they depend for inputs, transport and access to markets. Independent peasant (dekhan) farms are those with the status of separate juridical entities and the right $\mathbf{b}$ open their own bank accounts. They may hold leases of up to ten years. These are few in number and have been experiencing reverses rather than expanding. A TACIS report (1996) on the Samarkand district noted a decline in the number of independent peasant farms since 1995. The operations of peasant farms are, in fact, quite severely restricted since they have contracts with collective farms to grow particular crops under sharecropping arrangements. These frequently exceed the legal requirement of crops and quantities ( fifty per cent of wheat or cotton) they must deliver but farmers have weak bargaining power in setting the terms of their contracts. Furthermore, the collective farm is often in arrears of payments, leaving independent farmers strapped for cash, unable to pay for essential inputs or acquiring them by selling produce privately and therefore falling short of their contracted production quotas. Some private farms were closed down with reference to Article 13 of the Land Law stating that if land is not used properly it should revert to the collective. There are, therefore, significant structural obstacles to the development of this type of tenure.

The household survey in Andijan and Kashkadarya reflected the land tenure situation described above quite accurately. Out of 100 surveyed households, only one was 
identified as an independent peasant farm. This conforms to the official data (1.5 peasant farms per 1000 population, approximating 150-170 households) reported by Ilkhamov (op.cit.). The different categories of land tenure were also correctly identified. However, the precariousness of tenure from year to year was not adequately taken into account, leading to puzzling inconsistencies in the case of one particular village. Several households had mentioned rice as their most important marketable crop. However, the household plots reported and the crops grown on them did not include rice Upon closer scrutiny, it became apparent that this rice was grown on subsidiary plots (tamorka) allocated during the past season. In the current agricultural season, the shirkat decided to take this land back to plant cotton. One can only surmise that there had been a shortfall in cotton production quotas. That meant the allocations of tamorka land would only be made on wheat land after the harvest, allowing households to grow vegetables only, which are both perishable and much lower in value than rice. This decision had created consternation since household budgets would be depleted by this serious loss of income.

Another crop which made an unaccountable appearance in one of the households was several tons of onions reported as sold but not as grown on any of the plots to which the household stated having access to. It appeared that the head of the household had entered into a sharecropping arrangement with the brigade chief (the overseer and manager of work brigades) on the collective farm to plant onions after the wheat harvest in return for a proportion of the produce. The degree of formality involved in this and similar arrangements is not always entirely clear. A widow living with her married sons also reported their household had harvested four tons of carrots, one of which was given to the brigade chief "for the village kindergarten". Whether this transaction took place in the context of a formal sharecropping contract or not was, again, rather vague. What is quite clear, however, is that since land allocation continues to depend on collective farm managers this gives them considerable power. They have discretion over the quantity, quality and distance from the homestead of the plots leased out, over the terms of the lease and on whether a household is allocated land or not. In one particular instance, one household was in serious financial difficulty and had no land plots at all. It transpired that they had not been allocated any after a falling out with the head of the kolkhoz, two years ago.

Aside from the vagaries of relationships with collective farm managers, a more insidious underlying source of instability in current land tenure arrangements, and therefore of growing vulnerability, resides in the inevitable tensions arising from simultaneously attempting to provide villagers with a subsistence base (and even expanding it under the new Land Law) and establishing land as a commodity through the expansion and diversification of leasehold markets. Inevitably, the claims that rural households make to the land they are, in principle, legally entitled to cultivate may be curtailed by the competing claims and priorities of farm managers . Given the fact that kolkhoz employees who no longer receive wages have become more dependent than ever on subsistence farming (and the sale of their crops whenever possible) there is a limit beyond which local administrators may not squeeze them without creating serious distress and discontent. However, there are already signs that this delicate balance may be tilting away from the interests of smallholders.

It would appear that even the very partial process of commoditization initiated by agrarian reform in Uzbekistan has set in motion changes that are likely to result in 
new pressures on smallholder households. Better off households are able to enter into private hire arrangements with the tractor and combine drivers of the kolkhoz who get paid either in cash or in kind. But the shortage of cash and inability to pay for inputs has already meant that the level of mechanization has dropped considerably for the great majority. On the other hand, private ownership of tractors is rising and households that can command both farming implements and some capital may look further afield than their own village for land to lease. The notion that outsiders who are not members of the collective may thus receive access to land is bound to create great ambivalence and there is likely to be conflict between communal norms and expectations and statutory rights under the new legislation. ${ }^{9}$

There are also signs that changes in land tenure and in the composition of rural livelihoods are shifting the balance of gendered divisions of labour within households and creating new burdens for women. The increasing reliance on personal subsidiary plots has meant an intensification of women's input into subsistence farming. In addition, women constitute the majority of workers who are officially registered in work brigades. There has been an increasing feminization of labour on collective farms since perestroika. Men tend to allocate their time to more lucrative contract farming activities, trade or even casual labour as mardigar (daily labourers hired for construction or farm work) whose wages are higher than women's pay in agriculture. The wages women (and children) receive for the cotton harvest are considered too small and are sometimes referred to by men as 'cigarette money' although they often represent the only source of cash income since all other agricultural wages are paid in kind. Work on multiple plots (kitchen garden, additional subsidiary plots (tamorka), plots leased under contract and brigade work on the collective farm) produces a substantial intensification of women's labour input in the busy season in Andijan. In Kashkadarya, on the other hand, the combination of a herding and cereal-based domestic economy means that women who lose their employment in collective farms have no other work or income. The appearance of women mardigar in Andijan, seasonal workers hiring out their labour during the rice harvest, also suggests the emergence of an increasingly impoverished section of the village population. Male informants strenuously denied their existence, insisting that only men worked as casual workers. However, interviews with women suggested that some had started organizing all-female harvest teams with friends and were looking for seasonal employment. At the other end of the social scale, the wives of private dekhan farmers are also experiencing major changes in their work conditions. From being kolkhoz workers or public sector employees with attendant social benefits, they have changed into unpaid family labourers. At least one of the interviewees reported that cooking for all the hired help during the busy agricultural season created a heavy load which made the more leisurely pace of her former employment in the local administration seem enviable. Elson (1995) noted that market-oriented family farming systems in China and Vietnam have intensified gender gaps in health and education and led to an incipient 'market patriarchy'. Ilkhamov ( op.cit.) partly concurs with this analysis in the case of Uzbekistan but puts his emphasis on the inadequate development of markets and the fact that the subsistence-based household economy is coming to dominate rural livelihoods. It is far too early to judge what the impact of family-based commercial farming might be in Uzbekistan, but it already seems evident that greater reliance on family labour for subsistence and market-oriented activities is affecting sexual divisions of labour. 
It should be quite clear from the foregoing that this shifting landscape of access to land and wages means that livelihoods are now generated through a wider range of activities and take multiple forms. These have important implications for the calculation of household incomes.

\section{Household incomes: official, unofficial and informal}

In his study of the Soviet informal economy, Grossman (1989) made a conceptual distinction between the informal second economy which was outside legal regulation and informal incomes that derive partly from the second economy and partly from illegal transfers such as bribes, embezzlement and misappropriation of public resources. He suggested that informal incomes constituted a sizeable portion of household budgets and that these tended to increase in both absolute and relative terms as one moved from north to south (particularly into Transcaucasia and Central Asia) and from major urban centres to smaller cities and the countryside. In an earlier ethnography of a Siberian collective farm, Humphrey (1983) showed that some unofficial or illegitimate roles were, in fact, essential to the smooth functioning of enterprises and that they could be deployed to perfectly legitimate ends such as securing inputs or marketing kolkhoz produce. Other research evidence (Mars and Altman, 1992) also highlighted that the second economy thrived in a symbiotic, if not parasitic, relationship to the formal sector and was, in some senses, an outgrowth of specific types of malfunction inherent in the command economy itself. The transition to the market and the crisis of the public sector have occasioned significant changes in the context and extent of informal activities and created new patterns of informalization which complicate the calculation of household incomes considerably. Indeed, as Humphrey ( op.cit. ) notes in an update of her earlier work, the sphere of unofficial dealings which used to be kept in the background, both in view of its illegality and the fact that the official system of redistribution was still delivering, has now moved to centre stage as the arena where new survival strategies are enacted.

Rural households in Uzbekistan currently make ends meet through a combination of sources of livelihood. These are salaries and wages which may be paid in cash, in kind or through combinations of both, self-provisioning and sale or barter of produce from personal plots or animals, income from other trading or informal service activities and benefits and entitlements (such as pensions, child, maternity and invalidity benefits) which are paid in cash. The financial crisis of collective enterprises and the fact that they are chronically in arrears of wages has resulted in a tacit "informalization" of registered, official activities. Let us consider the case of a woman worker at the local poultry factory in a village of Andijan province. Her salary currently consists of eggs which she must take to market or sell to intermediaries who collect produce from households. This is received in payment for a registered, official job which to take a monetary form has to go through the medium of petty trading, an activity normally associated with the informal economy. Similar conditions apply to workers at the local towel factory, with a resulting periodic glut of towels on local markets whenever they receive their 'pay'.

The case of kolkhoz workers is equally complicated. Workers organized in brigades normally have responsibility for a specific acreage of land planted with cotton (commonly one hectare, hence the term hektardji) year round for which they receive only in kind payment, except for the wages received for picking cotton. As stated 
above, the vast majority of workers in this category are women. Their payment usually consists of basic necessities such as flour, cooking oil and rice. A calculation I made on the basis of money equivalents of these goods showed that it translates into a monthly income well below the official minimum wage (Kandiyoti, op.cit.). However, membership of the collective farm also gives employees access to necessities which they would otherwise have to pay for such as the cotton stalks they use as fuel and animal fodder and the ability to graze animals on kolkhoz land. As a result, the calculation of money equivalents for in kind payments becomes a less than precise exercise.

When payments in kind are not automatically translated into immediate contributions to the family budget, estimations of income become even more complicated. This point was graphically illustrated by the case of a villager who had grown melons and water melons on a plot of leased land and bartered them at the local commercial shop against one hundred cups and plates. These were meant not only for his own family but also for the trousseau of his daughter who was coming up to marriageable age. Acquiring crockery made the returns from his melons more inflation-proof than if he had received cash for them and will doubtless save him money in the longer run. This sequence of events also implies that his immediate need for cash was not so pressing and that he was sufficiently comfortable to cover himself against some future expenditure.

Finally, the calculation of unofficial wages presents even more intractable problems. By unofficial wage, I mean emoluments received privately by officially registered employees in the performance of their normal duties. Tractor and combine drivers on the kolkhoz do private work on the personal plots of villagers in exchange for a fixed cash payment per hectare, or a portion of the produce harvested in the case of combines. Although they pay for their own petrol, they use the machinery of the collective farm and do this work in lieu of wages. Workers in construction brigades may also work privately and offer their services for cash or wages in kind. ${ }^{10}$ Likewise, a hospital nurse may give injections privately when called upon by villagers in need of treatment. There is nothing novel in these types of activities which would normally go under the label of "moonlighting" or having a job on the side. The novelty resides in the fact that these incomes have superseded official incomes which nonetheless may continue to be reported in household surveys. Moreover, researchers may find that there is little consistency in reporting practices. One tractor driver in an Andijan village declared his private earnings, while another stuck to his fictitious monthly wage. Others were genuinely unable to put a figure on their earnings due to the fluctuating nature of the demand for their services.

There are other unofficial incomes of a far less innocent nature than the private sale of one's customary services. These are the bribes and extortions which those in commanding positions of administrative authority are able to exact from villagers. The example of bazarkoms, officials who allocate spaces in bazaars, was already cited as a position offering substantial scope for unofficial earnings. Ilkhamov ( op.cit.) also remarks that the scale of exactions by officials (such as traffic police) on roads between village and town is of such magnitude that it has become one of the major obstacles to the development of private farming. These types of incomes are, needless to say, not susceptible to detection except through the obvious discrepancies 
one sometimes encounters between declared incomes and ownership of consumer durables such as cars, videos and expensive furniture.

It would be quite accurate to say that there are significant differences between men's and women's relative abilities to command unofficial and informal wages, since the skilled/technical and administrative occupations are almost exclusively occupied by men. There is a pattern of deepening feminization of unskilled agricultural labour (which is now paid only intermittantly and in kind) while men tend to capture the more lucrative niches of market trading in the informal economy. This pattern is by no means new but builds upon existing cultural understandings of the marketplace as a male domain and the informal world of patronage and bribes as an exclusively masculine world. Nonetheless, certain categories of women, those who are older and freed of their domestic duties since they can rely on younger women for the upkeep of their households, may also be active in markets. However, they tend to occupy less advantageous positions in the retailing chain. Typically, women selling imported clothing items in markets (from China, India or Turkey) receive goods on commission from a wholesaler who has the capital to make bulk purchases. The wholesaler (usually male) passes on his wares to individual women for retailing at a minimum agreed price, with anything the women can make over that price retained as profit. This effectively protects the wholesaler from any losses which are passed on to the retailer who may end up making no or very small profits. Some of the women I spoke to insisted that the only way they could break this cycle was by acquiring capital of their own. Yet at this juncture the already exisiting wage and income gaps between the sexes, based on the concentration of women in lower paid, unskilled occupations, is turning into a "cash gap" in the currently cash starved economy of rural Uzbekistan. Especially in Kashkadarya, a less developed province, some women reported 'not seeing money at all' in response to a question on who keeps the money in their household.

In addition to these complications, I was able to identify what we might call phenomenological discrepancies in what respondents themselves consider as 'income'. In one household, pensioners' benefits and proceeds from the household plot were the only sources of livelihood. When asked what the major source of income of their household was, they insisted they had no source of income whatsoever. This occurred on several subsequent occasions. Since these families were plainly living off something, their insistence that they had no income at all needed interpretation. It became apparent that benefits were not perceived as income since this was something they were entitled to. As for the produce from their own plot, it all went towards self-subsistence. They earned no wage and therefore had no income. It was not simply a matter of whether they received cash or not, since pensions are paid in cash. It was more a question of defining what types of returns qualified as income so far as the respondents were concerned. I entertained the possibility that this might be a problem of translation since the Uzbek term daromad equally translates as profit. However, I was surprised to come across another household reporting pensions as their major source of income. Commenting on this discrepancy, I was informed that they were sufficiently poor to report their pensions. ${ }^{11}$ On the other hand, a sizeable proportion of registered workers receiving actual or theoretical wages did not report their wages as the major source of income of their households but mentioned their farming or animal husbandry activities instead. 
There are thus numerous sources of inaccuracy and possible bias in the reporting of household incomes. Some of these difficulties have to do with the nature of the incomes in question, others with a reluctance to reveal certain types of earnings and yet others relate to ways in which the meaning of 'income' itself is interpreted by respondents. The issue of interpretation became even more crucial in relation to questions concerning household expenditure.

\section{Household expenditure: here you see it, the re you don't}

Descriptions of the most important expenses incurred by households during the past twelve months took a variety of forms. In some cases, straightforward reporting of items, such as the repair or construction costs for a house, was followed by a specific sum of money spent. The purchase of consumer goods, such as a new battery for a car or a carpet, was likewise reported in monetary values. In other cases, outgoings were described as an outlay of animals, produce, cash or various combinations of these. The most common incidence of such combinations could be found in enumerations of the costs of a wedding feast, circumcision or funeral ceremony. In many households, these life cycle events were the most frequently cited source of major expenditure. A typical inventory of expenses might look as follows: two rams, one sack (fifty kgs.) of rice, one sack of flour, twenty litres of oil and ten kilograms of carrots. Deriving the money equivalents of these outlays was a relatively simple matter, frequently assisted by respondents' own mental calculations. Whether these constituted net expenses was another matter, given that the value of gifts received on such occasions may act to defray some of the costs. Nonetheless, these were cases where all outgoings, whether they took the form of cash, livestock or produce were acknowledged as expenses.

I was alerted to the possibility that the concept of expenditure may itself be subject to differing interpretations by some findings from a village in the province of Kashkadarya. Here, one household identified the largest item of expenditure as the payment of 6,000 sums for medical expenses for the treatment of the respondent's sick wife. In answer to a previous question, the same respondent had reported slaughtering two rams and one bull for various religious holidays and ceremonies (for iftorlik, the break of fast at Ramadan, for kurbanlik, the feast of sacrifice, and for a sunnat toy, the circumcision feast). Even the most superficial calculation suggested that the value of these animals far exceeded the amount reported as maximum expenditure, since a single ram would easily have fetched 6,000 sums. Yet these animals were not mentioned as expenditure. When I probed into this discrepancy, I was informed that these animals didn't count as expenditure 'because they were ours'. Whereas they had to spend cash for medical costs, and therefore reported it as a major expenditure, they were able to meet their ceremonial needs from their own flock. Besides, whereas sickness constituted and unexpected misfortune, the slaughtered animals went towards meeting religiously sanctioned obligations. Clearly, this household was not thinking about the worth of its animals in terms of their market value or in money equivalents, highlighting the extent to which the concept of expenditure itself is relative to the degree of monetization of the economy as a whole. 
Indeed, one of the characteristics of this particular village was the fact that few reported selling any of their produce on the market. This was a dry farming area with few marketable crops. Villagers grew wheat on their personal plots for their own consumption and some vegetables, if they could find water, but the principal form of wealth consisted in having animals, mainly sheep. Many necessities were obtained through barter and exchange. Only the poorest households reported that their women wove rugs (kelims) for sale on the market and when animals were sold as a means of raising cash for essentials this was a tell-tale sign of resource depletion. In addition, the actual cost of keeping animals was relatively minimal. The whole family, including children, participated in their care. Shepherding and taking animals to summer pastures could be achieved through informal arrangements with kolkhoz shepherds who added private flocks to those of the collective farm in exchange for an animal or two depending on the size of the flock. Similar arrangements could be transacted with kin and neighbours. This was also an area where most women reported having no access to cash at all and where gaps, the rotating savings associations reported in Andijan, were non-existent. As pointed out in my earlier discussion on incomes, women's discretion over money, and therefore expenditures, is drastically curtailed in a cash scarce economy where opportunities for earning wages are shrinking further.

This situation contrasts sharply with that of villages in Andijan province where the degree of monetization is much higher. In this area of irrigated farming many household smallholdings were producing crops for sale, particularly rice. The level of mechanization of production on even relatively small plots was considerable and the cost of production much higher. ${ }^{12}$ Transactions to obtain inputs (such access to fertilisers and machinery) were also monetized, whether payments were made in cash or in kind, since the money equivalents of in kind payments were carefully calculated. One of the most striking findings here was that even what used to be a communal reciprocal helping arrangement, hashar, (such as neighbours coming together to help build a house) now carries a hidden payment in the form of gifts considered to approximate the value of the services rendered. Unlike Kashkadarya many women were active participants in gaps, indicating a degree of discretion over money, although this generally applied to older women. The reporting of household expenditures in this region was more strictly monetized regardless of the type of outlays ( whether they consisted of money, animals or other products).

These contrasts between findings in different regions are hardly surprising if we remember that the calculation of costs may always be a relative matter. Even in the most industrialized countries of the North a householder keen on do-it-yourself who has just built himself a cabinet or a garden shed might report the cost of the materials purchased but treat his own labour as a 'free' resource (although it may be argued that the labour of this amateur has a less obvious market value than that of a good cow). The reason why this gains particular relevance in rural Uzbekistan at this point in time is that the ways in which costs and expenditures are reported are both diagnostic of the degree of monetization in any given locality and constitute an important baseline for monitoring the extent of penetration of a market economy. That is why rather than treating the concept of expenditure (or for that matter, income) as a self-evident, universal category (which implicitly presupposes a market economy) it may be more pertinent at this stage to achieve a better qualitative understanding of how these categories are mapped out and utilized in different locations. 


\section{Conclusion}

Post-Soviet transitions have prompted a search for new policy tools and methods of data collection. The measurement of living standards and calculations of poverty lines have promoted the use of quantitative techniques and sample surveys as privileged tools for the collection of policy-relevant information. I have argued throughout this paper that survey data is valuable only to the extent that it builds upon a solid bedrock of in-depth, qualitative information about the processes under investigation. In particular, in an environment where patterns of employment, redistribution and social provision are shifting rapidly the assessment of poverty requires a detailed understanding of new sources of vulnerability. The gendered practices and expectations leading to differential outcomes for men and women at different stages of their life cycles can only be fully apprehended through detailed and painstaking qualitative research. Using illustrations from a household survey carried out in four villages of the provinces of Andijan and Kashkadarya in Uzbekistan, I offered an analysis of the ambiguities surrounding five basic concepts; those of household, employment, access to land, income and expenditure. My findings suggest that not only are the processes and categories identified under these labels context-specific, but they are also likely to undergo further transformations as market reforms deepen.

This raises a host of methodological questions that are not amenable to easy, prescriptive answers within the scope of a brief paper. Nonetheless, some general observations can be made about crucial areas of indeterminacy that should receive particular attention in the design of household surveys. The first concerns the use of official records, such as selsoviet records, as sampling frames. These may or may not be adequate depending on the problem at hand. The illustrations provided in this paper suggest that households identified on the basis of village records do not necessarily correspond to self-contained budgeting and consumption units. A more exploratory approach should inform the choice of units of analysis. This is particularly pertinent in view of the fact that the ways in which domestic units organize themselves (or fail to do so) to secure their livelihoods and deliver mutual assistance may spell the difference between destitution and relative security. Furthermore, the data at hand already indicates significant disparities along gender and age lines in access to employment, income and leisure. As resources shrink and services (such as education and health) become more costly we may expect already existing intrahousehold disparities to become exacerbated. The tools we use should be up to the challenge of capturing and monitoring such changes.

The second observation concerns the effects of 'transition'. These may be crystallizing around a growing disjuncture between 'official' occupations and wages and what people actually do to make a living. This disjuncture is reflected in the reporting of employment and incomes in ways that make an accurate evaluation of both work status and household finances quite problematic. At this point in time, there is a tendency in rural Uzbekistan to carry on reporting wages that have now become fictitious and 'registered' occupations (tied to the workbook system) that may no longer be related to a household's main source of livelihood. This may not simply be put down to a reluctance to report informal earnings but may also reflect a genuine internalization of Soviet definitions of what constitutes a 'proper' job- one that not only brings wages but a range of entitlements and benefits. As this system gets 
progressively eroded, the tendency for reported occupations to fall into line with major income-generating activities will undoubtedly increase. The same applies to wages. It will be crucial to monitor whether already exisiting gender gaps in wages become aggravated as women lose access to cash incomes, an incipient but clearly visible trend in rural Uzbekistan.

The particular combinations of cash and in kind payments received at present and the 'informalization' of registered jobs described above all correspond to a particular phase of the transition process. This period of crisis of the public sector is accompanied in Uzbekistan, by an effort to keep as many workers as possible 'on the hough youth and female unemployment are officially recognized as causes for particular concern. The government of Uzbekistan has made it an explicit policy goal to avoid the worst excesses of the market observed in other countries of the former Soviet Union (Human Development Report, 1998) and to 'cushion' the social costs of transition. However, even the piecemeal agrarian reforms adopted are creating contradictions which are becoming apparent in the area of access to land. The simultaneous attempt to provide smallholders with a subsistence base while developing and diversifying leasehold markets in land is creating new tensions. It is difficult to see how the existing situation may be sustained indefinitely. The fact that the rural population (a majority of just over sixty per cent in Uzbekistan) still retains a toehold in subsistence farming and smallholder production for the market and that movements of population are highly regulated (although much less so than under the Soviet system) has meant that urban poverty has been growing but is relatively contained. There has not been a significant influx of rural-to-urban migrants to cities. On the contrary, both the emigration of non-indigenous nationalities, that are predominantly concentrated in urban centres, and the steep decline of urban wages has meant that, at least initially, there has been a slight decline in urban populations after independence. This situation may change drastically if rural livelihoods are threatened by further losses of jobs and access to land. This may deepen the feminization of agricultural work even further since there are indications that most seasonal migrants are men. The combination of the erosion of the welfare system and the squeezing out of smallholders may result in growing destitution unless vigorous programmes of rural industrialization and off-farm employment creation are established.

Finally, the calculation of household incomes and expenditures are currently complicated by the intricate mix of in cash, in kind, official, unofficial and informal payments. Furthermore, the reporting of incomes and expenditures may reflect different kinds of logic, depending on the degree of monetization of local economies. Whereas in one region (Andijan) all outgoings, regardless of the form they take (cash, produce or animals) are accounted for as expenses, in another region (Kashkadarya) variations were observed in whether households calculated their animal wealth in terms of market values. It may well be that the deepening of a market economy may bring about a homogenizing effect on the deployment of these categories. The use of sensitively designed, longitudinal surveys may not only serve to monitor these changes but may also make a substantial contribution to our currently limited understanding of transition from command to market economies in different regional and cultural contexts. We may yet break out of the poverty of methodology in assessments of poverty. 


\section{NOTES}

${ }^{1}$ The household survey was part of a broader project supported by a grant of the Department for International Development with participation from UNDP, Tashkent for a project titled 'Rural Domestic Economy and Female Labour Supply in Uzbekistan'. It was carried out in four villages with contrasting livelihood systems (irrigated farming, dry farming and animal husbandry and farming and rural industry) in the provinces of Andijan and Kashkadarya. Two interview schedules were used; a household interview and a women's interview conducted with all co-resident adult women in the household. My thanks are due to Nadira Azimova who acted as national consultant on this project.

${ }^{2}$ Gaps may involve single sex ( all-male or all female) or mixed sex participation and different levels of payment ranging from symbolic to substantial sums. The payments are inflation linked either by being calculated in dollars or, as in the case of Andijan, being pegged to the price of meat. Although no hard data exists on this question, my observations suggest that substantially higher sums circulate in all- male groups as compared to women's gaps.

${ }^{3}$ I choose to label these limitations as 'heuristic errors' since an analysis of the reasons behind some apparent inconsistencies and omissions effectively reveals how existing arrangements work and how respondents map out their worlds.

${ }^{4}$ The literature on agricultural development projects in sub-Saharan Africa, for instance, is rife with examples of how assumptions about households as income-pooling, corporate units come up against the actual realities of different customary practices. In cases where the automatic control of the male household head over the production and labour time of women cannot be taken for granted, and where projects make the assumption that such control exists, intensified intra-household conflict along gender lines is frequently reported.

${ }^{5}$ Despite legal entitlement to private plots, the actual probability of being allocated one depends on the availability of land. In Andijan province, where population pressure on land is extremely high, new allocations fell well below the legally allowed limit and many were actually denied land. In Kashkadarya much larger allocations of unirrigated land were made to households but lack of water limited what they could cultivate and many used the land to grow fodder crops.

${ }^{6}$ Admittedly, this only happened in two cases since divorce is relatively rare in villages. There is, however, a patrilineal bias in setting the boundaries of families. A disabled, single older brother receiving benefit is considered as part of the same family in a way that a divorced daughter can never be. However, in the event of remarriage a divorced daughter's children are frequently taken in by their maternal grandparents since it is considered unseemly for a woman to bring children from a previous marriage into her new husbands' household.

${ }^{7}$ This became quite clear to me in discussions with Uzbek colleagues who expressed utter disbelief at the notion that pension rights could be tampered with or redefined. Verdery (1996) was right in pointing out that the social compact between state and citizen under socialism was based on the paternalistic promise of being provided for at the cost of restrictions of one's personal freedoms in market and political terms. The elimination of the former in the absence of an expansion of the latter, as is currently the case in all Central Asian republics, could be the occasion of serious social disaffection and unrest.

${ }^{8}$ Some categories of skilled workers are better placed in this respect. For instance, a carpenter -builder registered in a construction brigade but receiving no wages can ply his trade privately and work during the construction season. Tractor and combine drivers are likewise able to do jobs on their own account. Unskilled agricultural workers are least able to command unofficial wages and shirkats try to make sure they, at least, get paid in kind. Cotton harvesting wages are always paid in cash on a five-daily basis since the supply of an adequate workforce during the peak season continues to be a problem.

${ }^{9}$ In the course of an interview with a farm manager, I tried to highlight the problems of leasing village land to outsiders by asking whether I would be permitted to lease and cultivate a plot if I came forward with the requisite capital. I was assured that I would be welcome to do so and that I would even find willing partners to join me in this farming venture. In reality, leaving aside any existing 
legislation barring foreigners from such enterprise, this would constitute quite a scandal and receive extremely negative evaluation whatever the formal rules might be.

${ }^{10}$ Some payments in kind are more appreciated than cash. Bottles of vodka, for instance, are inflationproof, just like dollars.

${ }^{11}$ I am indebted to Nodira Azimova for heated and lengthy discussions on the meaning of some of these inconsistencies. She found it self-evident that better off families would not consider benefits as income, whereas my own strictly monetary understanding dictated that all payments received must constitute income.

${ }^{12}$ I was particularly struck by the fact that the number of women working as casual wage workers (mardigar) at the rice harvest was not particularly high, although the very exis tence of such women represents a departure from past patterns. If we compare this to Southeast Asia where harvesting and processing rice constitutes an important source of income for poor rural women we may better appreciate the differences. However, the increase of manual operations in households who can no longer afford to pay for machines combined with rising unemployment on collective farms may well push up the demand for and the supply of casual workers.

\section{References}

Agarwal, B. (1990) 'Social Security and the Family: Coping with Seasonality and Calamity in Rural India', Journal of Peasant Studies 17 (3):341-412.

Couduel,A., McAuley, A. and Micklewright, J. (1997) 'Transfers and exchanges between households in Uzbekistan' in J.Falkingham et.al. (eds.) Household Welfare in Central Asia, pp. 202-20. London: Macmillan.

Buckley, M. (ed.) (1997) Post-Soviet Women: from the Baltic to Central Asia, Cambridge: Cambridge University Press.

Bruce, J and Dwyer, D.(eds.) ( 1988) A Home Divided: Women and Income in the Third World, Stanford: Stanford University Press.

Elson, D. (1995) 'Transition to the Market: Some Implications for Human Resource Development' in P.Cook and F. Nixson (eds.) The Move to the Market? Trade and Industry Policy Reform in Transitional Economies, pp. 41-56, London: Macmillan.

Evans, A. (1989) Gender Issues in Rural Household Economics, IDS Discussion Paper No. 254, Institute of Development Studies, University of Sussex, Brighton.

Falkingham, J. and Micklewright, J. (1997) 'Surveying Households in Central Asia: Problems and Progress' in J. Falkingham et.al. (eds.) Household Welfare in Central Asia, pp.42-60. London: Macmillan.

Grossman, G. (1989) 'Informal Personal Incomes and Outlays in the Soviet Urban tes et.al. (eds.) The Informal Economy,pp.150-70, Baltimore: The Johns Hopkins University Press.

Humphrey, C. (1983) Karl Marx Collective: Economy, Society and Religion in a Siberian Collective Farm, Cambridge: Cambridge University Press. 
The University of Michigan Press.

(1998) Marx Went Away-But Karl Stayed Behind, Ann Arbor:

Ilkhamov, A. (1998) 'Shirkats, Dekhqon farmers and others: farm restructuring in Uzbekistan', Central Asian Survey, 17 (4): 539-60.

Lubin, N. (1981) 'Women in Central Asia: Progress and Contradictions', Soviet Studies

XXXIII (2): 182-203.

Kandiyoti, D. (1998) 'Rural livelihoods and social networks in Uzbekistan: Central Asian Survey, 17(4):561-68.

Mars, G. and Altman, Y. (1992) 'A Case of a Factory in Uzbekistan: its Second Economy Activity and Comparison with a Similar Case in Soviet Georgia', Central Asian Survey, 11(2): 101-11.

Moghadam, V.M. (ed.) (1993) Democratic Reform and the Position of Women in Transitional Economies, Oxford: Clarendon Press.

Molyneux, M. (1994) 'Women's Rights and the International Context: Some Reflections on the Post-Communist States' Millenium, 23 (2): 287-313.

Moore, H. (1992) 'Households and Gender Relations: The Modelling of the Economy' in S.Ortiz and S. Lees (eds.) Understanding Economic Process New York: University Press of America.

Morris, L. (1984) 'Redundancy and Patterns of Household Finance', Sociological Review 33 (3): 492-523.

--- Constraints on Gender: The Family Wage, Social Security and the Labour Market', Work, Employment and Society,1 (1): 85-106.

Pahl, R. (1984) Divisions of Labour, Oxford: Blackwell.

(1988) 'Some Remarks on Informal Work, Social Polarization and the Social Structure' International Journal of Urban and Regional Research, 12 (2): 24767.

Spoor, M. (1995) 'Agrarian transition in former Soviet Central Asia: a comparative study of Uzbekistan and Kyrgyzstan', The Journal of Peasant Studies, 23 (1):46-63.

TACIS/Government of Uzbekistan (1996) 'Pilot Integrated Development Programme, Bulungur District, Samarkand, Uzbekistan’ Final Report BS6-Land Tenure, Tashkent.

UNDP, Human Development Report-Uzbekistan, Tashkent, 1998.

Verdery, K. (1996) What Was Socialism and What Comes Next, Princeton: Princeton University Press. 
Whitehead, A. (1981) 'I'm Hungry Mum: The Politics of Domestic Bargaining', in K. Young, C.Wolkowitz and R. McCullagh (eds.) Of Marriage and the Market London: CSE Books

Deniz Kandiyoti is Senior Lecturer in the Department of Development Studies at the School of Oriental and African Studies, University of London. She is the author of Women in Rural Production Systems (Unesco, 1985), the editor of Women, Islam and the State ( Macmillan,1991) and Gendering the Middle East ( I.B. Tauris, 1996) and is currently working on post-Soviet transitions in Central Asia, with special reference to agrarian reform in Uzbekistan. 